\title{
Labor Migration and the Missing Work of Home-making: Three Forms of Settling for Chinese-Canadian Migrants
}

Nathanael Lauster

Jing Zhao

University of British Columbia

Please note: the following is the POST-PRINT version of the paper published in:

Social Problems, Volume 64, Issue 4, 1 November 2017, Pages 497-512,

https://doi.org/10.1093/socpro/spw035

\begin{abstract}
Much of migration theory has come to revolve around the category of the "labor migrant," without taking into account labor, like home-making, that remains unrecognized by the market. Drawing from qualitative interviews with thirty one Chinese migrants in different stages of making a move from Beijing to Vancouver, we attempt to bring better visibility to how the labor involved in home-making intersects with migration. Defining home-making as work in the pragmatic-existentialist context of the stabilization of everyday routines, we uncover three themes to home-making work: settling in, settling down, and settling for. Discussion of these themes reveals two important issues for migration theory: settlement relies upon the work of home-making and the work of home-making in many cases motivates migration. For these reasons, the work of home-making should be more carefully studied within the migration literature.
\end{abstract}

KEYWORDS: immigration; settlement; home-making; China; Canada.

The authors wish to thank Gillian Creese, Amy Hanser, Pierette Hondagneu-Sotelo, Sean Lauer, Ruth Milkman, and Lori Wilkinson as well as the editor and anonymous reviewers at Social Problems for their many insights into improving the paper. This research was supported by grants from Metropolis British Columbia and the Social Science and Humanities Research Council of Canada. Direct correspondence to: Nathanael Lauster, Department of Sociology, University of British Columbia, 6303 NW Marine Drive, Vancouver, BC, Canada V6T 1Z1. Email:nlauster@mail.ubc.ca. 


\section{Introduction}

The work of home-making has important implications for the study of migration, but the migration literature has largely ignored the centrality of this work to the migration experience. Hence the "labor migrant" occupies a central place within migration theory, and the migrant appears primarily as homo economicus, or the economic man (Ley 2003). We make the work of home-making visible by analyzing qualitative interviews and collaboratively constructed maps exploring everyday life and routine within the context of migration patterns from Beijing to Vancouver. Our research reveals three key types of settlement work involved in home-making: settling in, settling down, and settling for. Consequently, we suggest that the work of homemaking is constitutive of the process of settling; a process requiring labor. Moreover, a cursory examination of the work of home-making reveals it to be a powerful motivating force for migration despite its general lack of recognition within the literature. For these reasons, we suggest that the otherwise invisible labor of home-making should occupy a more central place in broader discussions of labor migration.

\section{Separate Spheres and the Centrality of the Labor Migrant}

Feminists have widely pointed out the relative invisibility of home-making as work (e.g., Ferree 1990; Hanson \& Pratt 1988; Hartmann 1981). This invisibility dates backward to the cultural division of everyday life into separate spheres of "home" and "work" occurring during the industrial revolution and throughout the rise of the middle class (Frykman \& Löfgren 1987;

Gillis 1996). As the sphere of home was separated from the sphere of work, it became sacred in the process, placing home as the realm of women; a realm apart from and above market forces. 
This left the work of home-making mostly invisible and devalued at the same time as the experience of home came to serve as most peoples' primary means of symbolically carving out a space of comfort and resistance (Creese, Dyck \& McLaren 2008); a haven set against the heartless world of the labor market (Lasch 1977; Massey 1994).

The separation of spheres made its way into a variety of social scientific theories meant to describe social reality, and migration theory is no exception. From Ernst Ravenstein's (1885; 1889) early attempts to lay out the "laws of migration" onward, the market-oriented labor migrant has remained at the heart of migration theory (e.g. Castles 2010; Lee 1966; Massey 1988; Massey et al 1993; Piore 1976; Portes \& Rumbaut 1996). The labor migrant (typically perceived as masculine) tends to be viewed as disembedding and unsettling himself as he perceives market-generated opportunity elsewhere. He is assumed to calculate the costs and benefits involved in moving, transforming himself into homo economicus (the economic man) in the process. Markets are understood as driving migration. Hence, only market work matters.

As the study of migration became increasingly focused on work in the marketplace, the study of residential mobility became distinct, in part, by taking up the importance of home and housing, at least after the formative research of Peter Rossi (1955) and Curtis Roseman (1971). Later research on the relationships between work, home, mobility and migration increasingly tended to reinforce these distinctions (Dieleman \& Mulder 2002; Hanson \& Pratt 1988; Zax 1994). Home became that which was left behind in long-distance migration, but readily improved by short-distance mobility. Indeed, for Michael Piore (1976), in describing the rise of dual-labor markets, the ability to leave home behind was what enabled migrants to take the lowstatus jobs that locals did not want. Yet Piore thought that migrants would inevitably come to settle into their new environs, developing somewhat vague ties that transformed their new locale 
into home. Then they (or their children) would adopt the local value-system and become dissatisfied with the low status jobs on offer. Settlement seemed like a natural process for Piore (1976), as for other theorists that followed (e.g. Massey 1986). Home gradually transferred from one location to another, following moves toward market opportunities.

Feminist research in migration, as in other fields, challenged the idea that home just naturally appeared anywhere (Hondagneu-Sotelo 1995; 2011). Nevertheless, the focus remained upon labor markets as drivers of migration, so that feminist researchers described how international migration streams developed around women transforming themselves into paid domestic laborers, all in response to markets for housekeeping, cooking, childcare, and eldercare (Herrera 2013; Hondagneu-Sotelo 2001; Pratt 2012; Silvey 2004). The developing concept of "transnational motherhood" shook up the foundations of migration research, but much of the way that home-making matters remains underexplored within the literature, especially when carried on outside of the paid labor market. Making this work more visible offers both definitional and methodological challenges.

\section{Making Visible the Labor of Home-making}

Marxist-feminist researchers were at the forefront of bringing visibility to the work of home-making, in the process recasting the home as a site of struggle and contestation. They placed women's work broadly, and housework more specifically, at the center of "social reproduction," involving the intergenerational production and maintenance of people, a matter of fundamental importance to the broader reproduction of society (Hartmann 1981; Laslett \& Brenner 1989). Marxist-inspired feminist researchers acknowledged the co-dominance of both 
capitalist and patriarchal modes of production and social reproduction, opening new sites for struggle, as when women faced increased work burdens after neo-liberal policy makers cut back on welfare infrastructure (Bezanson \& Luxton 2006). Refining the theoretical definition at a more intimate scale, Evelyn Nakano Glenn (1992) provides a useful and expansive set of examples of what is involved in social reproduction work, including: "activities such as purchasing household goods, preparing and serving food, laundering and repairing clothing, maintaining furnishings and appliances, socializing children, providing care and emotional support for adults, and maintaining kin and community ties” (p. 1).

Other scholars, less engaged with political economic theory, describe many of the same tasks listed above simply as care-work, family work, or house-work (Coltrane 2000; HondagneuSotelo 2001). Time use studies employing these categorizations continue to reveal notable disparities, with most of this work being performed by women (e.g. Lee \& Waite 2005). Though we build upon all of the literature above, studying much the same sort of work, we strengthen the theoretical basis for its categorization as home-making work, with foundations in pragmatist and existentialist investigations into the nature of home (Blunt \& Dowling 2006).

From pragmatism, we emphasize the role of habit and routine in organizing the flow of everyday action (Gross 2009). Successful home-making produces the stability required to support habits and routines, enabling people to feel at home and relatively untroubled by the demands of unfamiliar situations (Lauster 2016; Wise 2000). Within the existentialist tradition, Martin Heidegger (1971) offers similar foundations. Home can be understood as constructed in the process of building up a source of ontological security with respect to everyday meaningmaking and identification (Dupuis \& Thorns 1998). Remaining mindful of feminist critiques (Mallett 2004; Massey 1994; Young 2002), we point toward home-making as the active work of 
stabilization required to produce a reliable base, made up of repetitive configurations of people, places, and things, around which both habits and meaning can form.

A pragmatist-existentialist foundation for investigating home-making provides a complementary theoretical perspective to that found within the social reproduction literature, similarly integrating the tasks of care work, family work, and house-work. It grounds this work within a conceptualization of home as a place built from reliable routines; one that "starts by bringing some space under control” (Douglas 1991, p. 298). Theories of home provide guidance for understanding what motivates and shapes the work of home-making and speak to its everyday salience. Of relevance to the present study, theories of home also suggest the importance of immigration as an especially useful site for viewing the work of home-making in action. The process of immigration is unsettling, necessarily entailing disruption of daily routines of habit, place attachment, and meaning-making. The work of home-making becomes especially palpable, and more amenable to study, for immigrants (Bracket 2012; Wise 2000).

Nevertheless, an important implication of highlighting the work involved in homemaking is that home is never entirely settled in the first place. It always requires work, and the work becomes more demanding as peoples' environments transform around them, especially through the political economic transformations highlighted by Karl Polanyi (1957) and Stephen Castles (2010) as well as by feminists like Kate Bezanson \& Meg Luxton (2006). In order to make the work of home-making visible as it bears upon immigration we should seek to observe the challenges people face in stabilizing their everyday routines before, during, and after the immigration process. Below we take up this challenge in examining the migration stream from Beijing, China to Vancouver, Canada. 
Labor Migration and the Missing Work of Home-making

\section{Chinese Migration to Canada}

Canadian immigration policy has always been driven by labor market concerns (Green \& Green 1999). Within this framework, Chinese migrants were frequently seen as especially dynamic economic actors, responding to and creating labor market opportunities within Canada (Ley 2003). Early on they were viewed as a readily imported form of cheap labor for nationbuilding projects, including especially the Canadian Pacific Railway. Politics painted these labor-oriented "sojourner" immigrants (Yang 2000) as threatening to the social fabric of Canada in the late $19^{\text {th }}$ and early $20^{\text {th }}$ century, and racist exclusionary acts were installed limiting Chinese immigration ( $\mathrm{Li} 1998)$.

In the post-WWII years race and national-origins based migration policies became less palatable and labor was once again in demand. Canada's Department of Citizenship and Immigration and its Department of Labor were consolidated into a joint Department of Manpower and Immigration in 1966, and a new skills and occupation-based point system for immigration was installed in 1967 (Green \& Green 1999). Here the policy agenda of Canada most closely came to rely upon the theoretical category of the "Labor Migrant." The new selection criteria were directly tied to Canadian labor-market needs, and once again welcomed Chinese migrants. To the "skilled" immigrant class was added the "business" immigrant class, including entrepreneur (1978) and investor (1986) programs, as Canada attempted to attract immigrants viewed as especially dynamic participants within the market economy (Ley 2003).

When Canadian immigration policies first opened up, residents of the People's Republic of China (PRC) on the Chinese Mainland were not generally permitted to leave (Li 1998). 
However, residents of Hong Kong and Taiwan began moving to Canada; especially as the crackdown on Mainland protests in 1989 renewed concerns over the impending handover of Hong Kong to PRC rule. As the PRC turned increasingly toward market-led growth through the 1990s, initiating a new round of social change and upheaval, China began to enable and encourage its residents to move abroad as well (Yu 2008). Since 1997, the Chinese Mainland has emerged as Canada's primary source of both Chinese migrants and, in most years, migrants overall (APFC 2014; Teo 2003; Yu 2008). By official classification, economic immigrants (skilled and business class) accounted for $70 \%$ of the total number of immigrants from China to Canada by 2005, a figure that has remained roughly stable since (APFC 2014; Yu 2008).

Throughout their return to Canada, Chinese migrants, whether from Hong Kong, Taiwan, or the PRC, have often been viewed as the very embodiment of market-oriented labor migrants and have frequently been courted as such by Canadian governments in hopes of growing the market economy (Ong 1993; Ley 2003; 2010). A variety of recent studies raise questions about this strategy, noting that businesses started by Chinese migrants often fail (Ley 2010), and many Chinese migrants end up with limited connections to the Canadian labor market (Man 2004; Teo 2003; Yu 2008). As a case study, Chinese migrants to Canada offer up both an idealized version of market-oriented labor migration and an empirical mystery regarding its failure. As a result, the migration stream is well positioned for exploring what can be learned by making the work of home-making a more visible aspect of the study of labor migration.

Within the broader flow of Chinese-Canadian migration, we focus specifically on the stream from Beijing to Vancouver. In human terms, the mega-city of Beijing, located at the political and cultural center of China with a population of nearly 22 million people, is nearly the size of all of Canada (population 32 million). A large portion of Canada's migrants flow through 
the city, where dramatic growth has resulted in both challenging living conditions and plans to remake the region on a metropolitan scale, effectively quadrupling its size (Johnson 2015). By contrast, the metropolitan area of Vancouver, located on the other side of the Pacific Rim, remains relatively small, at just over 2 million people (about 7\% of Canada's population), but contains nearly a third $(31.1 \%)$ of all of Canada's self-identified Chinese population. As a result Chinese migration influences Vancouver like nowhere else in Canada (Statistics Canada 2013). Of note, the large migration stream from Hong Kong in the 1980s and early 90s was met with local controversy, but as in the US, and in marked contrast to earlier eras, it remained primarily centered on concerns over the changing aesthetics of local development (Mitchell 2004; Saito 1998). More recently Chinese migrants have been blamed for the unaffordability of local housing (e.g. Bains 2016). Nevertheless, support for Canada's liberal immigration policies has remained exceptionally high relative to other receiving countries (Wilkes, et al 2008), and the perception remains that Vancouver is a particularly welcoming - if expensive - destination. Of relevance to the present project, and in marked contrast to Beijing, Vancouver is often touted as the most livable city in the world, with clean air and plentiful outdoor recreation opportunities (Punter 2003).

\section{Data and Methods}

For the present research project, three different cohorts of Chinese immigrants (prospective, recent, and more established) living in either Beijing or Vancouver were recruited for repeated in-depth interviews about their migration experiences and changes in everyday routine. The cohort model was designed to enable us to examine the daily lives of immigrants 
across the process of immigration. Samples were recruited through advertisements placed on two popular Chinese-language on-line immigration forums (http://forum.iask.ca/forums/ and www.ourdream.ca/forums/index.php). In total, eleven applicants for immigration to Canada lived in Beijing at the time of the interview awaiting final approval, nine recently arrived immigrants had moved from Beijing to Vancouver within a year of the interview, and eleven "more established" immigrants from Beijing, had been in residence in Vancouver for between 2 to 6 years. Nearly all applied to Canada as economic migrants (26 skilled, 4 business, 1 family). All interviews were carried out in Mandarin Chinese by the second author, with results translated into English here. In order to preserve confidentiality, interviewees have been provided with pseudonyms, with either Chinese or adopted English names provided according to how migrants presented themselves.

Women were more prominent than men in our sample, especially for recent migrants, a pattern reflecting broader Chinese migration trends. This likely relates to the transnational character of many immigrant families, where fathers often remain working in China while mothers and children work through the settlement process (Teo 2003; Waters 2002; Yu 2008). Aside from this pattern, Chinese migrants in our sample tended to mirror the characteristics expected of them by Canada's point system. Nearly all were well educated and well established in careers in China. They were generally in their late twenties to early forties, and tended to apply together with spouses and/or children.

In addition to their basic demographic data, we also asked immigrants a variety of questions about their feelings of home, their reasons for moving and settlement experiences, and their everyday lives before and after immigration. We paid special attention to their routines, and the sorts of work involved in putting those routines together. All migrants were interviewed 
twice, and in order to fully cue and capture the events of everyday life and gather a spatial sense for how they unfolded, immigrants were asked to map out their most recent day during each interview, describing how their routines at the time of the interview compared with preimmigration or projected post-immigration routines. By interviewing each immigrant twice within a short time-span, we asked for, and received, two snapshots of what their previous day looked like. These were used to inform the interview process itself and were compared to each other, to immigrants' assessments of what their normal routines entailed, and to their prospective and retrospective accounts of what daily life was expected to look like or used to look like. As such, though the research design was based in narratives about routines rather than direct observations, it grounded these narratives in the details of recent experience and enabled us to cross-validate descriptions of routines, both between interviews for any given immigrant, and across differing cohorts of immigrants.

\section{Findings}

Both interview and map data were analyzed with a grounded theoretical approach, developing and exploring theoretically relevant categories, or themes, for understanding the home-making work of interviewees (LaRossa 2005). The data revealed much of the work of home-making in both Beijing and Vancouver, interwoven into accounts of everyday life before and after migration as well as the problems people encountered in establishing routines. In our analysis, three theoretically informed themes emerged, tying home-making work to settlement as an ongoing process. We discuss home-making work as involved in: settling in, settling down, and settling for. 


\section{Settling In}

The work of "Settling in" involves assembling things and places together so they can support regular routines. Daily life needs to be assembled before it can be inhabited. Such interactions continue beyond the walls of one's housing, though control over these interactions may diminish. Overall, the work of insuring predictable comfort in people's interactions with place is house-work in perhaps its most recognizable form, including activities from Glenn's (1992) list, like "purchasing household goods, preparing and serving food, laundering and preparing clothing, maintaining furnishings and appliances." Nevertheless, the work involved in settling in can vary dramatically depending upon the upheaval and change people encounter in their everyday environment. Many migrants spoke of Beijing as a fundamentally unsettling place to live. As one migrant eloquently put it: "The environment is important, but it is not the big environment, it is your small surrounding environment." Challenges to stabilizing a "small surrounding environment" through home-making were often mentioned as motivations for coming to Canada.

Beijing's generally unsettling environment was made more intimate by many migrants, as they discussed the differences between their lives in Beijing and Vancouver in terms of air quality, noise, and especially food safety. Numerous food scares in China have clearly taken a toll on migrants' confidence that they could safely sustain themselves and their families (Hanser \& Li 2015). Wanda, who arrived as a skilled immigrant in 2008, described how her concerns about food safety in China continued to influence her purchasing patterns in Canada, noting: 
I buy organic foods at Save On Food \& Whole Foods. I seldom shop for groceries at T\&T [a Chinese-oriented Grocery Chain]. I think things imported from China might not be safe.

Similarly, Miao, a prospective immigrant preparing to leave Beijing with her husband and son, described how the air pollution and noise of the City were major factors in her decision. She declared, "I feel like I can't live in this environment anymore." Yet Miao also drew attention to the rapidly rising housing prices in Beijing. She described her history of dismay over their upward march, and declining accessibility; "I didn't think about immigration until the price of housing rose up so ridiculously high." In this way, broader issues of inequality were made more intimate in terms of how it was becoming more and more difficult to sustain a middle class existence in China. Jane, another prospective immigrant preparing to move with her husband and son, also longed for a cleaner environment, safer food, and cheaper housing. She reasoned through an explicit connection between inequality and the instability of everyday life in China:

It's reasonable that people with an undergraduate degree earn less than those with a master's degree, but at least everyone can afford a stable life in Canada. Not like here in China; giant gap.

Jane made her search for stability clear. Other migrants also drew connections between financial uncertainty in China and the ability to sustain a good life. Samantha had been in Vancouver the longest of all of the migrants we talked to, following her sister out of Beijing in 2005. She arrived with her husband and daughter, and the family added a son soon after landing. Even 
though she lived in relatively cheap work-unit housing before leaving China, Samantha found stabilizing other aspects of her life troublesome, including saving and driving:

In China, I dared not spend the money I earned. The housing wasn't a problem, but you couldn't build up any savings. It wasn't enough. Here the environment is good. I drive every day. I got my driver's license. But I wouldn't dare drive in Beijing. If I want to change lanes here, someone will wait for me. But not in China. So I like it here.

An additional issue for migrants was the political uncertainty in China. Migrants did not trust China's social welfare system to care for them. This had everyday implications for people, as they navigated local bureaucracies in order to get things done. Qiang, a prospective migrant waiting to move with his wife from Beijing to Canada, was looking forward to a simpler life in a fairer society. He described how he had to stop jogging in Beijing due to the air pollution, and his interest in Canada seemed partly driven by environmental conditions, but Qiang also expected he would be enabled to get a variety of pesky everyday tasks taken care of once he was free from China's uncertain regulatory regimes:

I checked on internet forums, and the service fees in Canada are expensive, but other things are cheaper compared to China. For example, the price of pork is cheaper, and it's safer. In terms of life, I expect things will work more smoothly. Just go through the process, which is clear and fair. If you have to wait, then just wait, you will get there in the end. But in China, you never know whether you will get there or not while waiting. 
You need to figure out where to do this, then when. It takes several times to get just one thing done... They don't tell you how and what is the procedure in one step.

The difficulty people had settling in to a stable life in China - especially a stable, middle-class life - motivated many migrants' moves to Canada. Migrants frequently compared the difficulties of settling in Canada to the difficulties of settling in China. For some, the comparisons left them yearning to return. But for most, even when they described difficulties settling in Canada, they seemed minor beside the difficulties they faced before immigrating.

Cheng, a recent business-class migrant who moved in to a suburb of Vancouver with her daughter about five months before she talked to us, neatly summarized the concerns that many other migrants also had about settling in to life in Canada. Cheng's husband remained in China and she thought she would return as well after her daughter finished her university education. But she also described feeling more settled in Canada over time, noting "I'm gradually feeling better about this place, more secure and adapted." She liked many of the environmental features of Canada that other migrants also described, but also noted the difficulties she faced in everyday terms; "complicated things become simple, and simple things become complicated."

Everyday aspects of her life that she took for granted in China became difficult to reassemble in Canada, even as problems that once seemed intractable more or less disappeared. Cheng described her difficulties in setting up an electricity account, finding someone to cut her hair, and navigating Vancouver's suburbs for everyday shopping:

It's very inconvenient. You have to drive for at least 15 minutes to shop for groceries at the supermarket. In Beijing, there are grocery stores everywhere. 
When she found a place to shop, she still had trouble figuring out how much she should be paying and what to buy. She couldn't read many English instruction manuals, and didn't know "how to consume" things. Like other immigrants, Cheng had difficulties finding many of the foods she liked, even at Chinese-oriented grocery stores, where she thought the majority of things carried were "Guangdong or Hong Kong style." She found the restaurants on offer much more limited than in Beijing, where she seldom cooked. In suburban Vancouver, she found herself cooking a lot, but unfortunately the kitchen didn't work the way she was used to; “the design is not proper for Chinese cooking." More generally, Cheng found it difficult to figure out how to fill up her days in Vancouver. She noted of Beijing:

I had more things to do: visiting my parents, meeting friends, exercising, visiting facial and hair salons to get beauty treatments, and shopping. There are a lot of places to hang out in China.

As a business-class immigrant, Cheng seemed to have ready access to family wealth. She described owning several apartments in Beijing. Nevertheless, as she explained it, she ended up taking a job in Vancouver cleaning a supermarket just to kill the time and meet people. In this sense, having a job provided an important source of structure for Cheng's everyday life. Zhen, another business-class immigrant, described taking a sales job in a local mall for much the same reason. For many people, work helps create an inhabitable routine. Paid work is taken on as part of home-making work. 
Both Cheng's and Zhen's entries into employment provide evidence that the importance of work for immigrants extends well beyond the income it provides. For many of those landing in Canada, work provides valuable organizational material for assembling the routines of home. Nevertheless, the experiences of Kevin, a migrant working as a technician in a less stable, shiftwork and on-call position, demonstrate that work can also be destabilizing. Kevin described how his daily routine depended upon the shift he took the day before. This left him feeling like he needed to do extra work symbolically demarcating the intimate boundaries of his apartment in order to feel like he could carve out a livable routine.

I just don't mess things up. I sleep in the bedroom, work in the office. A lot of people browse the internet or watch TV in the bedroom, but I don't do that. I watch TV in the living room. When I go to bed I just sleep.

Kevin came to live in Vancouver in 2006, followed by his new wife. But they divorced after three years. The divorce was related to Kevin's burgeoning desire to return to Beijing, where he found settling into a routine much easier. Not only did he feel it difficult to settle in to Vancouver, he also experienced difficulties settling down.

\section{Settling Down}

"Settling down" adds interpersonal complications to the effort involved in settling in. Settling down involves the stabilizing of interactions with people as well as with places and 
things. Other people, including children, tend to be disruptive of daily routines, unless a great deal of effort is expended to assemble and bind them to place and time. The home-making work of settling down enrolls the related work of settling in as part of making the world predictable for others, but it also extends beyond this work, insofar as settling down involves attempts to stabilize loved ones' lives more broadly, including by creating together time (Daly 2002). Returning to Glenn's (1992) list, settling down includes, "socializing children, providing care and emotional support for adults, and maintaining kin and community ties." It also means binding everyone's routines to one another, and is fundamentally involved in the construction of family.

Though Kevin's marriage fell apart in Canada, he could have managed to tie other relationships into a sustaining routine, constructing a new family for himself. But though he described "often hanging out with friends" back in Beijing, he found it difficult to relate to people in Vancouver. Bereft of stable relationships to other people, Kevin was ready to return to Beijing. This was striking, since most migrants described finding it much easier to settle down and establish close, regular, and caring relationships with their loved ones in Canada than in China - that is, as long as their loved ones came with them.

The primary reason it was easier for most migrants to establish more intimacy with loved ones in Vancouver than in Beijing was because of the hectic pace of life they described in urban China. Work kept many people from home for long periods of time. Evenings were frequently spent socializing - often as part of work obligations. This left little time for close relationships, with spouses, or with children. Michael, a recent migrant, provided us with a typical case. He came to Vancouver with his wife and son about a year before he spoke with us. He described his 
life in China as consisting of a lot of business trips. He wasn't home much. Like many other migrants from Beijing, Michael came to Canada in large part to get away from all of that:

I'm past the stage when I was young and struggled for a lot things. I wanted to have more time with my family.

Since Michael came to Vancouver, he began to stay home more. He described learning to cook, and taking on more chores after his wife became pregnant. Michael seemed to really enjoy his new, more leisured and home-oriented life. Though he was working on starting up a business, and expected "life would be different," once it got started, he didn't anticipate that things would ever get too busy in Canada.

Many migrants described situations where childcare and housekeeping duties were left to others in China; sometimes nannies and housekeepers, other times parents. Together with his wife, Tong, a recent immigrant, made enough money in Beijing to hire a nanny to look after their daughter while they worked. Tong often worked overtime in Beijing, took business trips, and spent evenings out, wining and dining colleagues. Like Michael, he described being at home very little. When he was home, he mostly spent his time recuperating on the couch, while the nanny, his parents and his wife's parents took turns looking after Tong's daughter.

Tong explained that his life since arriving in Vancouver was dramatically different. He had enough money to buy a house in an expensive neighborhood. On a normal day, he described waking up to cook breakfast and prepare lunch boxes for his daughter and wife. He took his daughter to school (his wife attended a college program), then he took an English class, watched TV, napped, and worked on his garden - a distinctly important sort of home-making labor for 
many migrants (Hondagneu-Sotelo 2014). In the afternoon he picked up his daughter to take her to afterschool programs and played with her through the evening. Tong planned to get some paid work eventually, as his English improved, but he seemed in no hurry.

Samantha had been in Vancouver much longer than Michael and Tong; long enough to establish her own housekeeping business, a form of market work often open to migrant women (Hondagneu-Sotelo 2001). Nevertheless, she also described her life as more oriented around her husband and children in Vancouver than in Beijing, where her family ties were more extended. In Beijing, Samantha worked late and ate dinner with her parents, who looked after her daughter during the day, while her husband ate dinner with his parents. Since Samantha moved to Vancouver, she had another child, and her husband began cooking dinner for the family. Effectively, her family relations became much more nuclear in orientation.

Notably, Samantha and Michael both described adding second children to their families after their arrival in Vancouver. For most, the addition of second children would have been fraught with added difficulty in the restrictive one-child policy regime enforced by China's punitive regulations. A variety of migrants described their desire for more children as partially motivating their move to Canada. Like others, Li, a 33-year old applicant hoping to move to Canada with her husband and son, was looking forward to a more relaxed life once she left her high-pressure job in Beijing. But Li also described how her desire for another child made the interminable waiting for approval from Canadian immigration authorities stressful.

My anxiety grew stronger as I thought about having a second child. I wanted another one but I was limited by the population policy. I can’t have another one until I immigrate to Canada. 
Li's concerns speak to the ways peoples' time-bound attempts to settle down into a family run on parallel clocks as their negotiations with immigration regimes. Here too, a desire for a more intense family life (as opposed to market work) motivated a move. Migration to Canada became a path to settling down to the everyday family life that many people still want to have. Concerns about children also motivated moves to Canada in another way. Parents were often concerned about schools in China. Many migrants felt that the standard education system in China was too rigid and demanding of their children, with alternatives too competitive or too expensive. Once again, a move to Canada provided a way out. Emily came to Canada as a business-class immigrant, and moved to a suburb of Vancouver with her husband and son about six months before she spoke to us. Schooling was a primary concern:

We decided to immigrate when my son was in third grade. He disliked going to school. He didn't want to do the homework. The teachers didn't like him. He didn't like the teachers. Kids in China have to attend extracurricular classes, like English and Olympic math. That's tough for both children and parents. They have to take all kinds of classes on weekends. Otherwise, they will fall behind.

With a move to Canada, Emily's son could spend more time with his family. Other migrants also described their moves to Canada as strongly motivated by schooling. Gessica moved to suburban Vancouver with her husband and daughter about one month before her interview with our project. She evocatively declared that many people were leaving China as "education refugees," uncertain whether they would be able to get their children into good schools without 
paying the enormous costs associated with "sponsorship fees." Gessica, a corporate finance director during her time in Beijing, calculated that moving to Canada had likely saved her 1.2 million RMB (over $\$ 200,000$ ) in costs on her daughter's twelve years of primary and secondary schooling.

Overall, most migrants described intensifying and investing in their family relationships with children and spouses through their arrival and experiences in Vancouver. Nevertheless, a few, like Kevin, experienced a divorce after migrating. A larger group - all women experienced a different kind of separation. They came to Vancouver and stayed with their children while their husbands returned to work in China. For women in these "astronaut families," migration left them spending more time with their children, but decidedly less time with their spouses (see also Waters 2002). In our sample, a mostly missing spouse made it more difficult for some migrants to settle down. It also ultimately challenged their ability to settle in. Some found their schedules unmoored when they lived alone. Others described the unsettling nature of family visits. Cheng described how when her husband visited, it added to the disorganization of her life by disrupting what routines she had managed to set in place. She found she had to cook more, buy more food, and give him priority over use of the car. The inability to settle her family down together made it more difficult for Cheng to settle in.

\section{Settling For}

"Settling for" less than ideal situations and outcomes is work of a different sort. More inherently emotional in nature than the work involved in settling in and settling down, settling for something involves simultaneously making sacrifices and making them invisible. The home- 
maker who settles for a situation achieves a measure of stability in exchange for giving up some emotional energy or social recognition that might otherwise be obtained. In effect, the making of home prioritizes the stability of home - for one's self and/or one's loved ones - over achieving higher status elsewhere. It also involves putting on a performance; often a happy face, as part of maintaining a stable environment. This sort of work helps keep the rest of home-making work invisible. As such, it is not explicitly included as an example of the labor of social reproduction in Glenn (1992). Nevertheless, "emotional labor" is well recognized within service work more broadly, and has also been recognized as a fundamental part of home-making work (Erickson 2005; Hochschild 1989; Laslett \& Brenner 1989).

Nearly all immigrants leaving Beijing simultaneously experienced the loss of a high status career. For many "skilled immigrants" this meant leaving behind the clearest demonstrations of their skill, and the loss of everyday status in a workplace that failed to recognize their credentials, eloquence, or talents was hard to swallow (Guo 2013; Man 2004). For immigrants like Kevin, this, too, was a key component of unhappiness in Vancouver. Kevin knew he could keep his shift-work job as a technician in Vancouver as long as he liked. But as he noted:

In China, I was a manager. If I go back with work experience from abroad, I'll get an even higher position. But if I stay here I'll just stay at the level of technician and won't become a manager or anything. I won't be fired until I retire, if I don't make any big mistakes. But I won't have as promising a future as in China. 
Kevin's narrative points toward one of the big reasons many men likely stayed behind in China, even as they sent the rest of their families to live in Vancouver. Though they might justify staying behind as the best way they could provide for their families, it is likely they also experienced difficulty settling for the less rewarding work-life on offer in Canada's labor market.

Though business class immigrants, like Cheng and Zhen, entered the country with documented wealth and took lower-status jobs primarily, as they put it, to help them settle in, for other migrants concerns about income were not easily disentangled from concerns about status or home-making. Indeed, having money made it much easier to settle in to place and settle children down in a good school. Judy used to be very job-oriented when she lived in China, and her husband remained there, working at a university. She felt privileged by her status as an engineer in China, and described how her life felt dull by comparison in Canada. Though she had lived in Vancouver with her two daughters for three years, she was considering returning to China. She wanted a good job again, a concern that tied together status, money, and stability for her children in ways she found difficult to resolve.

The key point is money; whether I can find a good job. I have to make a decision about going back or staying here. I need to settle my children down. It's not good for children to live here for two years, there for two years. They won't know who they are, where they belong. It's tough. But I need to make a decision.

For Judy, as for most migrants, remaining in Canada seemed to imply settling for a not-so-good job. On the whole, prospective migrants waiting to leave Beijing were well aware that their career prospects were likely to be more limited once they left. But for many, the trade-offs 
involved meant that settling for lower workplace status might be offset by gaining status in some other way. For instance, Xiao, considering the move, compared her status in China relative to Canada in a complicated fashion, weighing giving up work status against gaining rights as a citizen.

It's hard for me to make a final decision, considering the work position I have already achieved and the properties I own in China. I probably won't be able to find the same job there in Canada. But that's okay. We can live without working now in Beijing. We can live on our savings in Vancouver. And I've heard that the Canadian government takes care of you too. You never hear that the Chinese government cares about you.

Perhaps unusually, Xiao felt high status within her home, declaring of her husband's input into their migration trajectory: "my decision is our decision, he just obeys." Other prospective migrants, like Miao, didn’t feel they were losing out on much by leaving lower-status work situations in China. Miao had already quit a job in Human Resources to care for her son before preparing to move to Canada. In readying herself to return to market work after moving to Canada, she was happy to entertain the possibility of picking blueberries or delivering pizza for a living:

I like this kind of job. It's joyful and comfortable. So I don't worry about working. Other people, like university professors, are highly skilled. It's hard for them to find similar work. If they were respected here, doing manual work abroad would be tough for them. It's hard to look for a job with such high expectations. 
For Guan, another prospective migrant, though he was working as a financial analyst in Beijing, he was still living with his parents. This left him feeling like he hadn't accomplished much: "I don't have my own life; I don't have my privacy." When he received approval for his application to come to Canada, he called everyone:

I told them I made it! When I received the approval letter, I felt I did something. I hadn't achieved anything in my life yet. I made it this time!

Coming to Canada bestowed a kind of status on Guan that seemed to more than make up for any loss of professional identity. Though he expected "difficulty in finding a job" in Canada to match his position in Beijing, he didn't view this as a problem, noting: "no big deal for me; I can probably learn gardening." For several other migrants, the high-status Beijing job left behind came with more emotional anxiety than positive energy. Gessica, for one, was glad to escape her position in finance. Her concerns echoed those of a few others who felt uneasy about the unethical practices their jobs required of them in China. As she put it:

In our area, the higher the position you're in, the more risks you'll take. You know that you're not doing things properly. But you still need to get things done. So you never know what's going to happen next.

Altogether, the emotional work of settling for a lower status position, especially, but not solely in the workplace, was part of the work of home-making for immigrants from Beijing. It was made 
easier for those who felt they were gaining status in other ways and leaving risks behind. But this may have been the work that many men found the hardest to accomplish, leading to astronaut families where fathers and husbands continued to work in China. Vancouver often provides the materials for assembling a stable life, but workplace respectability and peer esteem frequently remain behind in Beijing.

\section{Discussion}

As suggested by pragmatist and existentialist literature, the work of home-making is foundational for making everyday life inhabitable and imbuing social interactions with meaning, implying that recognition of this work has important implications beyond labor studies. Due to the inherent disruptions involved, immigration operates as a key site for seeing home-making in action, and we document how migrants take on the work of settling in, settling down, and settling for their new environs. But we also demonstrate that this work is on-going, occurring prior to, throughout, and after the process of immigration. Taking this work seriously matters for migration theory in two important ways. First, migration is often undertaken as part of the work of home-making. Second the work of home-making is constitutive of the process of settlement. We begin by discussing the latter point, then return to the first.

A number of authors, including Piore (1979) and Massey (1986) have offered stylized portraits of settlement as a process, which all too often assume away the work involved (Hondagneu-Sotelo 1995). In narratives of migration experience from Beijing to Vancouver we note that the trajectory of settlement very nearly reverses that assumed by the scholars above. Migrants tend to settle in and settle down with their families first, enjoying leisure time and 
making a home. Then they gradually begin to look for market work. Often times they take jobs as part of settling in and stabilizing their lives into a new routine, rather than the other way around. This speaks, in part, to the privileged positions of many migrants from Beijing, but runs against the assumptions inherent in their categorization as skilled labor and business migrants (Ley 2003; 2010; Man 2004). It also fundamentally upends the idea that there might be a singular settlement trajectory led by market-oriented work.

Investigating the different types of settlement work involved is also important for improving understanding of settlement outcomes. Dividing settlement into different types reveals both the ways in which they complement one another, and the tensions between them. It seems when people can manage to work on settling in, down, and for, all at the same time, they are likely to meet with greater success in making a home for themselves. But the work of settling in to a relationship to place can be challenged by the work of settling down with other people, who may, or may not cooperate. Children, as ever changing and in need of settling, represent a special challenge to the home-making work of their caregivers, who frequently balance the demands of stabilization against efforts to improve the social position of their children. This relates to the broader notion that the ability to do the work of settling in and settling down may be challenged when people find themselves unwilling or unable to do the emotional work of settling for lower social status. Tensions between different forms of settling raise questions about Piore's (1979) findings, where acceptance of low status work comes first and settling in and down is assumed to naturally follow, and these tensions may be related to the many absentee Chinese fathers and husbands we noted.

If the work of home-making reveals important aspects of the settlement process, it also reveals important motivations for migration. Here the work of home-making helps solve an 
empirical puzzle. As noted above, and by other observers (e.g. Ley 2003; 2010; Teo 2003; Yu 2008), the government approved "economic migrants" leaving Beijing for Vancouver seem only marginally oriented toward Canadian labor markets. Recent immigrants seem quite aware of the de-skilling and discrimination they are likely to encounter in the Canadian workforce (Guo 2013; Man 2004). Why move then? Migrants seem less interested in transforming themselves into market labor or starting new time-intensive businesses than in stabilizing a good place to live. Though they are not oriented primarily toward labor markets, those moving from China to Canada should still be understood as labor migrants. Their moves are undertaken as part of the invisible labor of home-making.

The work of home-making complicates a naïve view of labor migration, where migrants are always drawn by market opportunities. Migrants can also be drawn by opportunities to lessen the burdens placed upon the invisible labor of home-making; to carve out a better home, more protected from the social transformations wrought by market and other forces. In this way, home-making brings the study of labor migration back into conversation with a number of other migration paradigms. Following Rossi's (1955) early work, home-making migration might be viewed, in part, as an extension of research on mobility rather than migration. But the distance involved and the crossing of national boundaries distinguishes these moves from Rossi's mobility, and both remain themes within narratives of migration from Beijing to Vancouver. Home-making migration might also be considered akin to a fuzzy form of forced migration, especially insofar as it is motivated more by push factors than pull factors (Castles 2003; Lee 1966). But it is important to note that despite the difficulties of settling in China, the migrants discussed above do not follow the same paths, experience the same immediately coercive threats and dire needs, or fit the same legal definitions as refugees. Home-making migration also seems 
similar to the new and promising paradigm of lifestyle migration (Hoey 2005; O'Reilly \& Benson 2009). Yet lifestyle migration emphasizes factors like the search for meaning and identity that seem mostly secondary to the everyday home-making work described as motivating migration above. Indeed, home-making migration remains motivated by work concerns - as with all labor migration - it's just that the work is purposely configured outside of and even in opposition to the market.

It is worth noting that the Beijing to Vancouver migration stream may prove unusual, insofar as it both highlights the extremes of urban livability and selects for a set of relatively privileged immigrants. Though we suggest the work of home-making is always part of settlement, it's likely that other migration streams will involve differing settlement trajectories. As a motivation for migration, home-making work may play a less prominent role elsewhere. But in order to assess how it matters to any migration stream, the work of home-making must first be made visible, ideally before, during, and after the process of immigration.

Of note, three features of the Beijing to Vancouver migration stream suggest that the work of home-making is likely to be of widespread importance elsewhere. First, Chinese skilled and business class immigrants have often been thought to exemplify the best and most productive sorts of market-oriented labor migrants. If the invisible work of home-making overwhelms market orientations amongst these exemplars of the dominant migration paradigm, it is likely key for understanding other migration streams as well. Second, the privileged nature of the migration stream suggests a class for whom the work of home-making in their country of origin remains the easiest. There is little reason to suspect that those facing more difficult homemaking prospects wouldn't also be strongly motivated by opportunities to stabilize their everyday living environments. Third, though China's transformation has received perhaps the 
most attention, as emphasized by Castles (2010), the context of rapid development challenges everyday livability across a wide swath of the globe. Many peoples are likely to experience an erosion of home-making prospects, promoting a migratory response.

What does this framework suggest for the immigration policies of Canada and other nations? It seems what may be attracting skilled and wealthy Chinese migrants to Canada is not the freedom of Canadian markets, but rather, following Polanyi (1957), the protections and adjustments Canada has put in place to protect its citizens from the dislocating forces of the market. Canadian policies are viewed as encouraging safety, stability, participatory governance, and the pursuit of family time. For the most part, Canada makes a better home for migrants, rather than a better labor market.

But Canada doesn't let just anyone make themselves at home. Instead, immigration policies differentiate sharply between categories of migrants. As demonstrated by Geraldine Pratt (2012), those whose journeys to Canada are most explicitly tied to labor markets especially labor markets created for paid domestic workers - have often been prevented by policy from making a home for themselves; forced to leave behind family and take up residence within their employer's housing. A more just policy would enable home-making for all and also bring in a wider swath of home-seekers. Currently the most skilled and wealthiest applicants, those already most protected from the dislocating forces of social transformation in their countries of origin, are best enabled to make a home for themselves in Canada. Investigations into the work of home-making suggest how Canada's immigration policies contribute to rather than ameliorate global inequality, revealing an invitation that reads: give us your energetically leisured, your wealthy, your elites yearning to breathe freely. 


\section{References}

APFC (Asia Pacific Foundation of Canada). 2014. Immigration Statistics. Retrieved May 22, 2014 (http://www.asiapacific.ca/statistics/immigration).

Bains, Camille. 2016. Foreign buyers crushing Vancouver home dreams as governments do little: study. Canadian Press. May $8^{\text {th }}, 2016$.

Bezanson, Kate \& Meg Luxton, eds. 2006. Social Reproduction: Feminist Political Economy Challenges Neo-Liberalism. Montreal: McGill-Queen’s University Press.

Blunt, Alison \& Robyn Dowling. 2006. Home. New York: Routledge.

Brickell, Katherine. 2012. “"Mapping' and 'doing' critical geographies of home.” Progress in Human Geography 36(2): 225-244.

Castles, Stephen. 2003. “Towards a Sociology of Forced Migration and Social Transformation." Sociology 37 (1): 13-34.

Castles, Stephen. 2010. "Understanding Global Migration: A Social Transformation Perspective." Journal of Ethnic and Migration Studies 36(10): 1565-1586.

Coltrane, Scott. 2000. "Research on Household Labor: Modeling and Measuring the Social Embeddedness of Routine Family Work.” Journal of Marriage and Family 62(4): 1208-1233.

Creese, Gillian, Isabel Dyck \& Arlene Tigar McLaren. 2008. “The 'Flexible’ Immigrant? Human Capital Discourse, the Family Household, and Labour Market Strategies.” Journal of International Migration and Integration 9(3): 269-288. 
Daly, Kerry. 2002. “Time, Gender, and the Negotiation of Family Schedules.” Symbolic Interaction 25(3): 323-342.

Dieleman, Frans \& Clara Mulder. 2002. “The Geography of Residential Choice.” Pp. 35-54 in Residential Environments: Choice, Satisfaction, and Behavior. Edited by J. I. Aragonés, G. Francescato, \& T. Gärling. London: Bergin \& Garvey.

Dupuis, Ann \& David Thorns. 1998. "Home, home ownership and the search for ontological security." The Sociological Review 46(1): 24-47.

Erickson, Rebecca. 2005. "Why Emotion Work Matters: Sex, Gender, and the Division of Household Labor.” Journal of Marriage and Family 67(2): 337-351.

Ferree, Myra Marx. 1990. "Beyond Separate Spheres: Feminism and Family Research.” Journal of Marriage and Family 52(4): 866-884.

Frykman, Jonas \& Orvar Löfgren. 1987. Culture Builders: A Historical Anthropology of Middle-Class Life. Rutgers: Rutgers University Press.

Gillis, John R. 1996. A World of Their Own Making: Myth, Ritual, and the Quest for Family Values. Cambridge, MA: Harvard University Press.

Glenn, Evelyn Nakano. 1992. "From Servitude to Service Work: Historical Continuities in the Racial Division of Paid Reproductive Labor.” Signs 18(1): 1-43.

Green, Alan G., and David A. Green. 1999. “The Economic Goals of Canada’s Immigration Policy: Past and Present." Canadian Public Policy 25(4): 425-451. 
Labor Migration and the Missing Work of Home-making

Gross, Neil. 2009. “A Pragmatist Theory of Mechanisms.” American Sociological Review 74: 358-379.

Guo, Shibao. 2013. "Economic integration of recent Chinese immigrants in Canada's secondtier cities: The triple glass effect and immigrants' downward social mobility." Canadian Ethnic Studies 45(3): 95-115.

Hanser, Amy \& Jialin Camille Li. 2015. “Opting Out? Gated Consumption, Infant Formula and China's Affluent Urban Consumers.” The China Journal 74:110-128.

Hanson, Susan \& Geraldine Pratt. 1988. "Reconceptualizing the Links between Home and Work in Urban Geography." Economic Geography 64(4): 299-321.

Hartmann, Heidi. 1981. “The Family as the Locus of Gender, Class, and Political Struggle: The Example of Housework." Signs 6(3): 366-394.

Heidegger, Martin. 1971. Poetry, Language, Thought. New York: Harper \& Row.

Hochschild, Arlie. 1989. The Second Shift. New York: Viking Penguin.

Hoey, Brian. 2005. "From Pi to Pie: Moral Narratives of Noneconomic Migration and Starting Over in the Postindustrial Midwest.” Journal of Contemporary Ethnography 34(5): 586-624.

Hondagneu-Sotelo, Pierrette. 1995. "Beyond "The Longer They Stay" (and Say They Will Stay): Women and Mexican Immigrant Settlement.” Qualitative Sociology 18(1): 21-43.

Hondagneu-Sotelo, Pierrette. 2001. Domestica: Immigrant workers cleaning and caring in the shadows of affluence. Berkeley: University of California Press. 
Labor Migration and the Missing Work of Home-making

Hondagneu-Sotelo, Pierrette. 2011. “Gender and Migration Scholarship: An Overview from a $21^{\text {st }}$ Century Perspective.” Migraciones Internacionales 61(1): 219-233.

Hondagneu-Sotelo, Pierrette. 2014. Paradise Transplanted: Migration and the Making of California Gardens. Berkeley: University of California Press.

Johnson, Ian. 2015. "Chinese Officials to Restructure Beijing to Ease Strains on City Center." New York Times, July 11, 2015. http://www.nytimes.com/2015/07/12/world/asia/china-beijingcity-planning-population.html? $\mathrm{r}=0$

LaRossa, Ralph. 2005. “Grounded Theory Methods and Qualitative Family Research.” Journal of Marriage and Family 67(4): 837-857.

Lasch, Christopher. 1977. Haven in a Heartless World: The Family Besieged. New York: Basic Books.

Laslett, Barbara \& Johanna Brenner. 1989. “Gender and Social Reproduction: Historical Perspectives." Annual Review of Sociology 15: 381-404.

Lauster, Nathanael. 2016. The Death and Life on the Single-Family House: Lessons from Vancouver on Building a Livable City. Philadelphia: Temple University Press.

Lee, Everett. 1966. “A Theory of Migration.” Demography 3(1): 47-57.

Lee, Yun-Suk \& Linda Waite. 2005. 'Husbands' and Wives' Time Spent on Housework: A Comparison of Measures." Journal of Marriage and Family 67(2): 328-336. 
Labor Migration and the Missing Work of Home-making

Ley, David. 2003. "Seeking Homo Economicus: The Canadian State and the Strange Story of the Business Immigration Program." Annals of the Association of American Geographers 93(2): 426-441.

Ley, David. 2010. Millionaire Migrants: Trans-Pacific Life Lines. Oxford: Blackwell-Wiley.

Li, Peter S. 1998. Chinese in Canada, 2nd ed. Toronto: Oxford University Press.

Mallett, Shelley. 2004. "Understanding home: a critical review of the literature." The Sociological Review 52(1): 62-89.

Man, Guida. 2004. Gender, Work, and Migration: Deskilling Chinese immigrant women in Canada. Women's Studies International Forum 27: 135-148.

Massey, Doreen. 1994. “A Place Called Home?” Pp. 157-173 in Space, Place, and Gender. Minneapolis: University of Minnesota Press.

Massey, Douglas. 1986. “The Settlement Process Among Mexican Migrants to the United States.” American Sociological Review 51(5): 670-684.

Massey, Douglas. 1988. "Economic Development and International Migration in Comparative Perspective.” Population and Development Review 14(3): 383-413.

Massey, Douglas, Joaquin Arango, Graeme Hugo, Ali Kouaouci, Adela Pellegrino, \& J. Edward Taylor. 1993. “Theories of International Migration: A Review and Appraisal.” Population and Development Review 19(3): 431-466.

Mitchell, Katharyne. 2004. Crossing the Neoliberal Line: Pacific Rim Migration and the Metropolis. Philadelphia: Temple University Press. 
Ong, Aihwa. 1993. “On the Edge of Empires: Flexible Citizenship among Chinese in Diaspora." Positions 1(3): 745-778.

O’Reilly, Karen \& Michaela Benson. 2009. “Lifestyle Migration: Escaping to the Good Life?” Pp. 1-14 in Lifestyle Migration: Expectations, Aspirations and Experiences. Edited by M.

Benson \& K. O’Reilly. Surrey: Ashgate.

Piore, Michael. 1979. Birds of Passage: Migrant labor and industrial societies. New York: Cambridge University Press.

Polanyi, Karl. 1957 (1944). The Great Transformation: The political and economic origins of our time. Boston: Beacon Press.

Portes, Alejandro \& Ruben Rumbaut. 1996. Immigrant America: A Portrait. Second Edition. Berkeley: University of California Press.

Pratt, Geraldine. 2012. Families Apart: Migrant mothers and the conflicts of labor and love. Minneapolis: University of Minnesota Press.

Punter, John. 2003. The Vancouver Achievement: Urban Planning and Design. Vancouver: UBC Press.

Ravenstein, Ernst G. 1885. “The Laws of Migration.” Journal of the Royal Statistical Society 48(2): 167-227.

Ravenstein, Ernst G. 1889. “The Laws of Migration.” Journal of the Royal Statistical Society 52: $241-301$. 
Roseman, Curtis. 1971. "Migration as a Spatial and Temporal Process." Annals of the Association of American Geogrpahers 61(3): 589-598.

Rossi, Peter. 1980. Why Families Move. $2^{\text {nd }}$ Edition. Beverly Hills: Sage.

Saito, Leland. 1998. Race and Politics: Asian Americans, Latinos, and Whites in a Los Angeles Suburb. Champaign: University of Illinois Press.

Silvey, Rachel. 2004. "Power, difference and mobility: feminist advances in migration studies." Progress in Human Geography 28(4): 1-17.

Statistics Canada. 2013. Immigration and Ethnocultural Diversity in Canada. Ottawa: Ministry of Industry.

Teo, Sin Yih. 2003. "Dreaming Inside a Walled City: Imagination, Gender and the Roots of Immigration.” Asia and Pacific Migration Journal 12(4): 411-438.

Townsend, Nicholas. 2000. The Package Deal: Marriage, Work, and Fatherhood in Men's Lives. Philadelphia: Temple University Press.

Waters, Johanna. 2002. 'Flexible Families? 'Astronaut' households and the experiences of lone mothers in Vancouver, British Columbia.” Social \& Cultural Geography 3(2): 117-134.

Wilkes, Rima, Neil Guppy, \& Lily Farris. 2008. “'No Thanks, We’re Full’: Individual Characteristics, National Context, and Changing Attitudes Toward Immigration.” International Migration Review 42(2): 302-329.

Wise, J. Macgregor. 2000. "Home: Territory and Identity.” Cultural Studies 14(2): 295-310. 
Yang, Philip. 2000. “The 'Sojourner Hypothesis' Revisited.” Diaspora: A Journal of

Transnational Studies 9(2): 235-258.

Young, Iris Marion. 2002. "House and Home: Feminist Variations on a Theme." Pp. 314-346

in Gender Struggles: Practical Approaches to Contemporary Feminism. Edited by C. Mui \& J.

Murphy. Lanham, MD: Rowan \& Littlefield.

Yu, Li. 2008. “An Empirical Study of Recent Mainland Chinese Migration to Vancouver.”

Journal of the Canadian Historical Association 19(2): 180-196.

Zax, Jeffrey. 1994. "When is a move a migration?" Regional Science and Urban Economics

24: 341-360. 